\title{
Genetics in Suicide Treatments, Modern Diagnosis Establishments
}

\author{
Lu DY' ${ }^{1 *}$, Lu TR ${ }^{1}$, Che JY1, Yarla NS ${ }^{2}$ and Wu HY' \\ ${ }^{1}$ Shanghai University, Shanghai 200444, PR China \\ ${ }^{2}$ Gitam University, $A P$, India
}

\begin{abstract}
Antidepressants can relief human depression and reduce human depressive symptoms-including human suicide prevention. Although the mechanisms of action for these drugs remained to be established, researches focusing on revealing the relationship between efficacy and toxicities of antidepressants have been initiated in China and US. To deal with this suicide prevention and side-effective, new initiatives and revolutionary ideas have been proposed and assessed. Hopefully, therapeutic efficacies and outcomes by antidepressant treatments can be improved for clinical trials in future.
\end{abstract}

Keywords: Human genome; Human suicide; Drug response; Mental disorder; Genetic diagnostics; Medicinal chemistry; Next generation sequencing

\section{Introduction}

Human suicide is a common symptom of depression/mental illness worldwide [1-7]. Owing to long term economic depression in recent years, human suicide might still persist among most countries. In order to reduce human suicide, some good examples and paradigms have been speculated and systematical investigations have been underway [1-7].

\section{Past Achievements of Suicide Therapy}

PG technology detecting genes of many biological or pharmacological interests is mainly divided into two general categories-predicting risks and response of drugs and drug absorption, distribution, metabolism and excretion (ADME) by polymorphisms of human drug metabolizing enzymes or abnormal neural molecular targets. Approximately 300 human metabolic enzymes have been found. The genetic polymorphism changes of metabolizing enzymes decrease or increase the blood concentrations of antidepressants by different rates of drug ADME, which decide main parts of drug toxicities in human bodies. The side effects (risks) predictions of different types of antidepressants in determine polymorphisms of ADME are relatively less dramatic and severe, such as fatigue and vomiting etc. [4-7]. Drug-toxic molecules and drug-targeted molecules are proposed to be different mechanisms of action in many ways. Neural molecules or receptors have been proposed to be major gene encoding for both the suicidal ideations occurrence (risk) and therapeutic responses/ outcomes [1-7]. How to systematically study the mechanisms of action that genes or biological molecules involve in suicide occurrence and therapeutics has been proposed early before. Favorable outcomes have been reported in this respect [8].

The best gene candidates for suicide therapy are not very clear now. Genetic panels affecting both drug-active and drug-toxic genes (molecules) in the same times might be optimal avenues for in-depth scientific investigations [9-16]. Other current achievements relating antidepressant drug therapies are offered in Table 1.

\section{Medicinal Chemistry}

Antidepressant agents belong to different categories of biological, genetic or molecular mechanisms or chemical molecules. Presently specifically genetic or molecular study for each antidepressant agent, such as citalopram etc. is the first step [17-21]. In future, finding the relationship between chemical structures of antidepressant agents and their impacts on different individuals may prove to be more potential and clinical significance. Similarly, it needs more money in conventional routes [17-18]. Can we brainstorm more efficient assessment systems? May we invent or apply some new patents that focus on this matter and be potential future trends? [4].

\section{Technical Details}

Like many biomedical factors aforementioned, laboratory facility supports and technical details also determine the quality of experimental and clinical study outcomes and are important avenues for further updating clinical therapeutic protocols and medication efficacy [22-24]. Previously, the severity of drug risks and drug responses are decided by different toxicity symptoms. Integration of these two different symptom score systems as a whole is the first step testifying previous arguments and triggering genetic investigations determining and predictions of drug risks and responses in one PG system and other interesting topics [22-27].

Collecting data of relationship between chemical, genetics, environmental factors and therapeutic efficacy/outcomes is unavoidable study for in-depth understanding many important problems relating to previous speculations. Moreover, worldwide cooperation for accumulating rare inheritable disease-cases and sufficient GWAS

\begin{tabular}{|l|l|}
\hline Animal models and studies & $\begin{array}{l}\text { Optogenetics } \\
\text { GEM }\end{array}$ \\
\hline Clinical PG studies & $\begin{array}{l}\text { Human metabolic enzymes, such as } \\
\text { CYP2D6 } \\
\text { Drug-active or drug-toxic genes (SNPs) }\end{array}$ \\
\hline $\begin{array}{l}\text { Genome-wide association studies } \\
\text { (GWAS) }\end{array}$ & $\begin{array}{l}\text { More than 10 genetic allels are } \\
\text { discovered }\end{array}$ \\
\hline Other biological systems & Molecular Bioinformatics \\
\hline
\end{tabular}

Table 1: Brief outlines of current achievements relating to antidepressant therapies.

*Corresponding author: Dr. Lu DY, School of Life Sciences, Shanghai University, Shanghai 200444, PR China, Tel: +862166163545; E-mail: ludayong@shu.edu.cn Received September 18, 2017; Accepted September 25, 2017; Published October 04, 2017

Citation: Lu DY, Lu TR, Che JY, Yarla NS, Wu HY (2017) Genetics in Suicide Treatments, Modern Diagnosis Establishments. J Ment Disord Treat 3: 145 doi:10.4172/2471-271X.1000145

Copyright: (c) 2017 Lu DY, et al. This is an open-access article distributed under the terms of the Creative Commons Attribution License, which permits unrestricted use, distribution, and reproduction in any medium, provided the original author and source are credited. 
Citation: Lu DY, Lu TR, Che JY, Yarla NS, Wu HY (2017) Genetics in Suicide Treatments, Modern Diagnosis Establishments. J Ment Disord Treat 3 : 145. doi:10.4172/2471-271X.1000145

(genome wide association study) data [9-16] is avenue to expedient the study of many important issues of drug neural toxicity and therapies.

\section{Genome-Wide Associate Study (GWAS)}

Invitation of genome-wide association study (GWAS) of suicide and antidepressant therapy PG might lead to the final solutions for predicting neural toxicity (risks) and responses of antidepressants to normal human beings. By taking GWAS, more than ten genetic allele difference between normal and antidepressant susceptible humans have been found. But only half of these alleles are statistical significance now. It may be explained as being affected by other genetic or environmental factors or shortages of human genomic sample sizes [22-25]. Next generation sequencing (NGS) techniques will increase the speed of genome sequencing (15,000-50,000 times) and dramatically reduce the cost of genome sequencing (less than seven thousand US dollar for one genome) [4-7]. In future, genome sequencing working forces and researchers may be changed from biomedical major students into mathematical or physics major students or scholars. The contributions by mathematics and physics students or scholars for genomic sequencing will be more significant than biomedical majored students because of the increasing importance of large scale data manipulations or analysis in NGS protocols. Moreover, after large scale PG study, antidepressant treatments will be sophisticated and more effective for each patient in future.

\section{Other Technology}

On the other hands, some basic biological, pharmacological and toxicological information changes after antidepressant treatments, such as optogenetic studies $[25,26]$ or genetic engineering mice (GEM) [27] and other new technologies and patents must also be used to assess many opening hypotheses and systematic scientific studies, including this one and finally update antidepressant therapy PG and other clinical diagnostic and therapeutic systems. The techniques of optogenetic and genetic engineering mice (GEM) are new endeavors that can be used to study the functions and dysfunctions of specific genes in living bodies. Nonetheless, they are newly discovered technology and large flood of these approached and antidepressant therapy study will be soon done. Only then, many longstanding controversies can be resolved. So in future, a lot of intrinsic related things behind these differences can be discovered and better achieved by increasing worldwide cooperative efforts and activities in this regards. These researches will make great difference and impacts on antidepressant therapies in future. They are not only on medicinal chemistry, but also on pharmacology and toxicology topics.

\section{Clinical Treatments}

There is no therapeutic ideology for suicide origination now. Several types of diseases, such as mental disorders are possible targets for drug intervention [16,28-30].

\section{Conclusion}

In future, modern diagnostics for suicide and treatments in clinics might be strengthened. Increasing mandatory genetic/molecular/ image diagnostic trials might be required in most advanced countries in future. Or even become a worldwide indispensable.

\section{References}

1. Lu DY (2017) Suicide Risks and Treatments New Ideas and Future Perspectives. Lu DY (ed.) Nova Science Publishers.

2. Lu DY, Lu TR, Lu Y, Cao S (2017) Introduction for suicide study. Journal Metabolic Syndrome 6: 227
3. Lu DY, Wu HY, Cao S, Lu Y, Yarla NS, et al. (2017) Historical analysis of suicide/mental disorder and current diagnostics in clinics. Suicide Risks and Treatments, New Ideas and Future Perspectives. Nova Science Publishers.

4. Lu DY, Lu TR, Che JY, Zhu PP (2014) Genetics and bioinformatics studies of antidepressant drug therapeutic efficacies and toxicities, a current overview. CNS Drug Discov 9: 193-199.

5. Lu DY, Lu TR, Zhu PP, Che JY (2015) Genetics and bioinformatics study of antidepressant drugs, recent advancements and future trends. Suicidal Ideation: Predictors, Prevalence and Prevention. Weaver B (eds.), Nova Science Publishing.

6. Lu DY, Lu TR, Zhu PP, Yarla NS, Wu HY (2017) Current suicide prediction prevention and treatments. Suicide Risks and Treatments, New Ideas and Future Perspectives. Weaver B (ed.) Nova Science Publishers.

7. Serafini G, Salano P, Amore M (2015) Suicidal ideation: A comprehensive overview. Suicidal Ideation: Predictors, Prevalence and Prevention. Weaver B (ed.) Nova Science Publishing.

8. While D, Bickley H, Roscoe A, Windfuhr K, Rahman S (2006) Implementation of mental health service recommendations in England and Wales and suicide rates, a cross-sectional and before-and-after observational study. Lancet 379 . 1005-1012.

9. Menke A, Samann P, Kloiber S, Czamara D, Lucae S (2012) Polymorphisms within the metabotropic glutamate receptor 1 gene are associated with depression phenotypes. Psychneuroendocrinology 37: 565-575

10. Brent D, Melhem N, Turecki G (2010) Pharmacogenomics of suicidal events Pharmacogenomics 11: 793-807.

11. Kim DK, Kim JW, Kim SW, Bernard J (2014) Method for providing information on antidepressant therapeutic effect using single nucleotide polymorphism.

12. Laje G, Allen AS, Akula N, Manji H, Rush AJ, et al. (2009) Genome-wide association study of suicidal ideation emerging during citalopram treatment of depressed outpatients. Pharmacogenet Genomics 19: 666-674.

13. Garriock HA, Kraft JB, Shyn SI, Peters EJ, Yokoyama JS, et al. (2010) A genome wide association study of citalopram response in major depressive disorder. Biol Psychiatry 67: 133-138.

14. Uher R, Perroud N, Ng MY, Hauser J, Henigsberg N, et al. (2010) Genomewide pharmacogenetics of antidepressant response in the GENDEP project. Am J Psychiatry 167: 555-564.

15. Menke A, Domschke K, Czamara D, Klengel T, Hennings J, et al. (2012) Genome-wide association study of antidepressant treatment-emergent suicidal ideation. Neuropsychopharmacology 37: 797-807.

16. Lu DY, Zhu PP, Wu HY, Yarla NS, Zhu H (2016) Human suicide study, is there an associations between suicide and mental illness. Metabolomics 6: 186.

17. Lu DY, Lu TR, Ding J (2007) May genetic factors play a role in the risk of antidepressant-induced suicide. Med Hypotheses 69: 1380-1381.

18. Lu DY, Lu TR, Zhu PP (2010) Undesired neural side-effects of a drug, a chemical and genetic interrelated problem. Central Nervous System Agent Medicinal Chemistry 10: 108-112.

19. Mc Allister-Williams R, Ferrier IN (2009) Pharmacological management of unipolar affective disorder. Psychiatry 8: 113-119.

20. McAllister-Williams R, Ferrier IN (2009) Pharmacological management of bipolar affective disorder. Psychiatry 8: 120-124.

21. Lu DY, Lu TR, Ding J, Wu HY, Yarla NS, et al. (2017) Therapeutic drug developments and clinical utilities. Suicide Risks and Treatments, New Ideas and Future Perspectives. Lu DY (ed.) Nova Science Publishers.

22. Lu DY, Lu TR, Zhu PP (2012) How can we pinpoint genetic involvement in antidepressant-induced suicide? Adv Pharmacoepidemiol Drug Safety 1: 101.

23. Lu DY, Lu TR, Zhu PP (2013) Pharmacogenetics in neural toxicities of drugs. Pharmacogenomics $14: 1129-1131$.

24. Lu DY, Lu TR, Zhu PP, Che JY (2016) The efficacies and toxicities of antidepressant drugs in clinics, building the relationship between ChemoGenetics and Socio-Environments. Cent. Nerv. Syst. Agents Med. Chem 16: $12-18$

25. Kuo HW, Liu C, Tsou HH, Liu SW, Lin M, et al. (2013) CYP1A2 genetic polymorphisms are associated with early antidepressant escitalopram metabolism and adverse reactions. Pharmacogenomics 14: 1191-1201. 
Citation: Lu DY, Lu TR, Che JY, Yarla NS, Wu HY (2017) Genetics in Suicide Treatments, Modern Diagnosis Establishments. J Ment Disord Treat 3: 145. doi:10.4172/2471-271X.1000145

Page 3 of 3

26. Zhao Y, Xiong N, Liu Y, Zhou YH, Li NM, et al. (2013) Human dopamine transporter gene: differential regulation of 18-kb haplotypes. Pharmacogenomics 14: 1481-1494.

27. Youngtrom IA, Strowbridge BW (2012) Visual landmarks facilitate rodent, spatial navigation in virtual reality environment. Learn Mem 9: 84-90.

28. Kapur N, Gask L (2009) Introduction to suicide and self-harm. Psychiatry 8: 233-236.
29. Lu DY, Lu TR, Zhu PP, Cao S (2017) Different ranges of outside factors upon human suicidal rates and mortalities. Suicide Risks and Treatments, New Ideas and Future Perspectives. Lu DY (ed.) Nova Science Publishers.

30. Cornelius JR, Walker JD, Klima G, Fisher B (2015) Suicidal symptoms among veterans with chronic PTSD evaluated for treatment at a VA hospital. Suicidal Ideation: Predictors, Prevalence and Prevention. Weaver B (ed.) Nova Science Publishing. 